\title{
ACETYLCHOLINE METABOLISM IN RAT SPINAL CORD CULTURES: REGULATION BY A FACTOR INVOLVED IN THE DETERMINATION OF THE NEUROTRANSMITTER PHENOTYPE OF SYMPATHETIC NEURONS ${ }^{1}$
}

\author{
MARIE-CLAUDE GIESS AND MICHEL J. WEBER ${ }^{2}$ \\ Centre National de la Recherche Scientifique, Laboratoire de Pharmacologie et Toxicologie Fondamentales, \\ 31400, Toulouse, France
}

Received October 7, 1983; Revised December 12, 1983; Accepted December 13, 1983

\begin{abstract}
Acetylcholine metabolism has been studied in sister cultures of E13 rat spinal cord cells cultured for 1 to 3 weeks with or without conditioned medium (CM) from rat skeletal muscle cells. Spinal cord cells grown with $\mathrm{CM}$ synthesized and accumulated 3 to 4 times more $\left[{ }^{3} \mathrm{H}\right] \mathrm{ACh}$ from $\left[{ }^{3} \mathrm{H}\right]$ choline than cultures grown without $\mathrm{CM}$. This effect of $\mathrm{CM}$ was accompanied by a comparable increase in CAT activity and could not be mimicked by increasing the density of the spinal cord cultures. A 2to 3-fold increase in AChE activity was also observed in 2- to 3-week-old CM cultures, whereas the activity of lactate dehydrogenase was identical in cultures grown with and without CM.

We have compared the effects of $\mathrm{CMs}$ from various non-neuronal cell cultures on $\left[{ }^{3} \mathrm{H}\right] \mathrm{ACh}$ synthesis and storage by spinal cord cultures and by sympathetic neuron cultures. CM by skeletal muscle $>$ skin fibroblasts $>$ rat heart muscle $>\mathrm{C}_{6}$ glioma cells were the most active on both types of neuron cultures, whereas CM from rat brain, $\mathrm{L}_{6}$ myoblasts, mouse $3 \mathrm{~T}^{\prime} 3$, and PY'T21 fibroblasts was inactive on spinal cord cultures and only weakly active on sympathetic neurons. Serum-free $\mathrm{CM}$ from skeletal muscle was inactive on both types of neuron cultures.

The CM factor active on spinal cord cultures has been purified several thousand-fold by using a four-step fractionation scheme which has previously led to a partial purification of the CM factor involved in the regulation of $\mathrm{CAT}, \mathrm{AChE}$, and catecholamine-synthesizing enzymes in sympathetic neuron cultures (Swerts, J. P., A. Le Van Thai, A. Vigny, and M. J. Weber (1983) Dev. Biol. 100: 1-11). Moreover, a comparison of dose-response curves established with this purified material showed that it exerted its effects on spinal cord and on sympathetic neuron cultures in the same range of concentration. Thus, these results suggest that the same macromolecule is involved in the regulation of neurotransmitter phenotype in both types of cultures despite their different embryological origins.
\end{abstract}

Several phases in the development of the somatic motoneurons in vertebrate spinal cord $(\mathrm{SC})$ have been delineated from studies involving the ablation of their field of innervation. Neuroblast migration and proliferation and the initiation of differentiation, including early neurite outgrowth, occur independently of the developing

\footnotetext{
${ }^{1}$ We thank M. E. Sauron for helpful commentaries and for performing the experiment of Figure 1, and Dr. D. Paulin for the gift of antisera. Drs. F. Cuzin and R. Whalen gave us various cell lines. We are grateful to Dr. A. C. Kato for fruitful suggestions and for her help with the manuscript. This work was supported by funds from the Centre National de la Recherche Scientifique and the Institut National de la Santé et de la Recherche Médicale.

${ }^{2}$ To whom correspondence should be addressed.
}

musculature. At later stages, a rapid cell death is observed in the lateral motor column after extirpation of a limb bud, with the period of maximal sensitivity being concomitant to the episode of naturally occurring cell death in this SC structure. During late embryonic and postnatal development, the ablation of a limb first causes a chromatolysis reaction in motoneurons, eventually followed by a delayed cell death (Prestige, 1967, 1970; Wang and Oppenheim, 1978a, b; Oppenheim et al., 1978). The survival and growth of other cholinergic neurons in the CNS, the so-called visceral motoneurons, are also controlled by their target cells, the sympathetic and parasympathetic postganglionic neurons (Narayanan and Narayanan, 1978; Oppenheim et al., 1982; Schäfer et al., 1983). It is now commonly assumed that, during a certain 
period of their development, the survival and the differentiation of motoneurons are controlled by diffusible factor(s) released in limiting amounts by the muscles. This hypothesis has gained much support from the study of the role played by nerve growth factor (NGF) in the development of sympathetic and sensory neurons (see Hamburger, 1980).

The clucidation of the trophic interactions between muscle cells and motoneurons has made considerable progress by means of cell culture techniques. Macromolecules present in muscle extracts or muscle conditioned media (CM) have been implicated in motoneuron survival (Bennett et al., 1980) and neurite outgrowth in SC cultures (Dribin and Barrett, 1980; Henderson et al., 1981, 1983; Smith and Appel, 1983). Moreover, it has been found that the co-culture with skeletal muscle cells caused an increase in choline acetyltransferase (CAT) activity in rodent SC cell cultures (Giller et al., 1973, 1977; Meyer et al., 1979). A similar effect was demonstrated with muscle CM (Giller et al., 1977; Brookes et al., 1980; Godfrey et al., 1980) and with muscle extracts (Smith and Appel, 1983), suggesting that the influence of muscle cells on cholinergic maturation is at least in part carried by a diffusible factor(s). However, little is known about the molecular properties of these molecules (Godfrey et al., 1980; Smith and Appel, 1983). On the other hand, chick myotubes were found to have only a marginal effect on $\left[{ }^{3} \mathrm{H}\right]$ acetylcholine $(\mathrm{ACh})$ synthesis by chick embryo SC cell cultures (Berg, 1978).

In the past few years, we have been engaged in the characterization and purification of a factor present in $\mathrm{CM}$ from a variety of non-neuronal cells, including skeletal muscle cells, which modifies the neurotransmitter phenotype of cultured rat sympathetic neurons without affecting their survival and growth (Patterson and Chun, 1977). When maintained in the presence of this factor, neurons dissociated from newborn rat superior cervical ganglia (SCG) acquire progressively the ability to synthesize and store $\left[{ }^{3} \mathrm{H}\right] \mathrm{ACh}$ from $\left[{ }^{3} \mathrm{H}\right]$ choline and to form cholinergic synapses among themselves, whereas their adrenergic character is depressed (Patterson, 1978; Swerts et al., 1984b). The active factor in CM from muscle cells or C6 glioma cells (henceforth SCG-CMF) has been purified several thousand-fold (Weber, 1981; Weber and Le Van Thai, 1982; Swerts et al., 1983). Sympathetic neurons grown for several days in its presence display a 25 - to 100 -fold increase in $\mathrm{C} \Lambda \mathrm{T}$ activity as well as a 2- to 5-fold decrease in activities of AChE, tyrosine hydroxylase ( $\mathrm{TOH})$, dopa decarboxylase (DDC), dopamine- $\beta$-hydroxylase (DBH) (Swerts et al., 1983; Wolinsky and Patterson, 1983) and monoamine oxidase A (Pintar et al., 1981).

In the present study, we have envisaged a possible relationship between SCG-CMF and the muscle CM factor(s) involved in CAT regulation in $\mathrm{SC}$ cultures (henceforth SC-CMF). We first defined conditions which allow (1) the growth of SCG and SC neuron under similar culture conditions and (2) the comparison of the effects of the same muscle CM on both types of neuron cultures. Our data strongly suggest that SCG-CMF and SC-CMF are closely related macromolecules. This report is a part of a study aimed at delineating the target cell specificity of SCG-CMF. We demonstrate elsewhere that this partially purified factor also increases CAT activity in neuron cultures from rat nodose ganglia (C. Mathieu, A. Moisand, and M. J. Weber, submitted for publication). Thus, this factor appears to regulate CAT activity in derivatives from three different embryonic structures: the neural crest, the neural tube, and the epibranchial placodes.

\section{Materials and Methods}

\section{Culture media}

$L-15-\mathrm{CO}_{2}$ medium. The composition of this medium was described in detail by Hawrot and Patterson (1979). It is a Leibovitz L-15 medium with modified osmolarity, buffered al $\mathrm{pH} 7.4$ with sodium bicarbonate and imidazole, and supplemented with aspartic acid, glutamic acid, cystine, $\beta$-alanine, vitamin $\mathrm{B}_{12}$, inositol, choline chloride, lipoic acid, biotin, $p$-aminobenzoic acid, fumaric acid, and $\mathrm{CoA}$. The medium was filtered on prewashed $0.2-\mu \mathrm{m}$ Nucleopore filters (Pleasanton, CA) and stored at $4^{\circ} \mathrm{C}$ in the dark.

Hanks' saline solution. This solution contained (milligrams per milliliter): $\mathrm{NaCl}(800), \mathrm{KCl}(40), \mathrm{KH}_{2} \mathrm{PO}_{4}(6)$, $\mathrm{CaCl}_{2 .} \cdot 2 \mathrm{H}_{2} \mathrm{O}(18.6), \mathrm{MgCl}_{2} .6 \mathrm{H}_{2} \mathrm{O}(10), \mathrm{MgSO}_{4} .7 \mathrm{H}_{2} \mathrm{O}$ (10), $\mathrm{Na}_{2} \mathrm{HPO}_{4} \cdot 7 \mathrm{H}_{2} \mathrm{O}(9)$, and glucose (100). It was filtered and stored as indicated above.

Growth medium for non-neuronal cells. L-15- $\mathrm{CO}_{2}$ medium $(90 \mathrm{ml})$ was supplemented with $5 \mathrm{ml}$ of adult rat serum and $5 \mathrm{ml}$ of a solution (Mix) containing 2000 units $/ \mathrm{ml}$ of penicillin, $2000 \mu \mathrm{g} / \mathrm{ml}$ of streptomycin, 40 $\mathrm{mM}$ L-glutamine, $1 \mathrm{mg} / \mathrm{ml}$ of 6,7 -dimethyl-5,6,7,8-tetrahydropterine, $100 \mathrm{mg} / \mathrm{ml}$ of ascorbic acid, $10 \mathrm{mg} / \mathrm{ml}$ of glutathione, and $12 \%(\mathrm{w} / \mathrm{v})$ glucose (Hawrot and Patterson, 1979). This medium was stored either at $4^{\circ} \mathrm{C}$ for less than 10 days or at $-20^{\circ} \mathrm{C}$.

Culture medium for sympathetic neurons. L-15- $\mathrm{CO}_{2}$ medium $(90 \mathrm{ml})$ was supplemented with $5 \mathrm{ml}$ of Mix, 5 $\mathrm{ml}$ of adult rat serum, and $1 \mu \mathrm{g} / \mathrm{ml}$ of $7 \mathrm{~S}-\mathrm{NGF}$ from mouse saliva (Burton et al., 1978).

Culture medium for spinal cord cells. A series of experiments was performed to adapt to $\mathrm{SC}$ cultures the medium used for sympathetic neurons. A mixture of $5 \%$ each fetal calf serum and horse serum resulted in a much better neuronal survival than $5 \%$ adult rat serum. We also made the chance observation that $\mathrm{SC}$ cultures synthesized and stored about 2-fold more $\left[{ }^{3} \mathrm{H}\right] \mathrm{ACh}$ when grown in $\mathrm{CM}$ diluted with Hanks' saline than when grown in CM diluted with L-15- $\mathrm{CO}_{2}$, although the dilution of L-15- $\mathrm{CO}_{2}$ medium with Hanks' had no effect on $\left[{ }^{3} \mathrm{H}\right] \mathrm{ACh}$ synthesis and storage by culture grown without CM (data not shown). Elevated $\mathrm{K}^{+}$concentrations have beneficial effects on neuronal cultures from CNS and PNS (Lasher and Zagon, 1972; Bennett and White, 1979; Chalazonitis and Fischbach, 1980; Nishi and Berg; 1981a). Kato and Rey (1982) found that $36 \mathrm{~mm} \mathrm{KCl}$ was optimal for CAT development in ciliary neuron cultures, and this concentration was selected for SC cultures. Thus, the medium used for SC cells contained $(100 \mathrm{ml}$ final): $\mathrm{L}-15-\mathrm{CO}_{2}$ medium or CM, $50 \mathrm{ml}$; Hanks' saline, $45 \mathrm{ml}$; Mix, $5 \mathrm{ml}$. This medium was further supplemented with $36 \mathrm{~mm} \mathrm{KCl}$ and $5 \%$ each fetal calf serum and horse serum. 
Plating medium. This medium used for dissections was similar to the plating medium of Hawrot and Patterson (1979) except that the glucose concentration was $1.5 \%$ $(\mathrm{w} / \mathrm{v})$.

\section{Spinal cord cell cultures}

Rat embryos (14 days' gestation) were removed from timed pregnant rats (Wistar strain, Iffa-Credo, France) and were dissected in plating medium. The spinal cord was cut caudal to the bulb, freed of sensory ganglia and adhering meninges, and triturated with a fine-bore Pasteur pipette in $0.6 \mathrm{ml}$ of plating medium supplemented with $10 \%$ FCS. The suspension was then decanted, and the supernatant was centrifuged for $3 \mathrm{~min}$ at $1200 \times \mathrm{g}$ and resuspended in $\mathrm{L}-15-\mathrm{CO}_{2}$ medium with $20 \%$ FCS. The operation was repeated twice, and the supernatants were pooled to obtain a suspension containing $10^{7}$ cells/ $\mathrm{ml}$. The dissociated cells were plated in 24-well plates (Costar, Cambridge, MA) or 96-well plates (Nunc, Denmark) coated with poly-L-lysine. For coating, the wells were filled with $300 \mu \mathrm{l}$ or $50 \mu \mathrm{l}$ of $10 \mu \mathrm{g} / \mathrm{ml}$ of poly-Llysine (Sigma) in water, incubated at room temperature for $2 \mathrm{hr}$, and rinsed twice with Tyrode's saline. In general, $1.5 \times 10^{5}$ cells were plated per $16-\mathrm{mm}$ diameter well containing $500 \mu \mathrm{l}$ of spinal cord cell culture medium or $0.75 \times 10^{5}$ cells per $6-\mathrm{mm}$ diameter well containing 100 $\mu \mathrm{l}$ of medium. The corresponding cell densities were, respectively, $0.75 \times 10^{5}$ and $2.6 \times 10^{5}$ cells $/ \mathrm{cm}^{2}$. The cultures were incubated at $37^{\circ} \mathrm{C}$ in a $95 \%$ air $/ 5 \% \mathrm{CO}_{2}$ atmosphere. The medium was first renewed after $96 \mathrm{hr}$ and then three times a week. The cultures were not treated with antimitotic drugs. When used, muscle CM or purified fractions were given from the first day of culture.

\section{Cultures of rat sympathetic neurons}

Sympathetic neurons from newborn rat cervical superior ganglia were cultured as described by Hawrot and Patterson (1979) with minor modifications (Swerts et al., 1983). The cultures were treated with $10 \mu \mathrm{M}$ cytosine arabinoside between days 0 and 6 to eliminate ganglionic non-neuronal cells.

\section{Cultures of non-neuronal cells and CM}

Pectoral and abdominal muscles from newborn rats were dissociated with a mixture of $0.25 \%$ trypsin and $0.25 \mathrm{mg} / \mathrm{ml}$ of collagenase. Newborn rat skin and heart were dissociated with 0.5 to $1 \mathrm{mg} / \mathrm{ml}$ of collagenase (selected lots from Boehringer Mannheim, Germany). PYT21 fibroblasts were a gift from Dr. F. Cuzin (Nice) and L6 myoblasts from Drs. C. Pinset and R. Whalen (Paris). $\mathrm{C}_{6}$ glioma cells were from the American Type Culture Collection. Cells were grown in $150-\mathrm{mm}$ tissue culture dishes (Lux Scientific Corp., Newbury Park, CA) until they reach confluency. Fresh medium was then provided, and CM was collected after $24 \mathrm{hr}$. The operation was repeated until the cultures detached from the dishes. Secondary and tertiary cultures were obtained by mild trypsinization. 'The cultures were grown in $850-\mathrm{cm}^{2}$ plastic roller bottles (Corning) spinning at $2 \mathrm{rpm}$. CM was stored at $-20^{\circ} \mathrm{C}$ for several months with no loss of activity.

\section{Assay for $\left[{ }^{3} \mathrm{H}\right] \mathrm{ACh}$ synthesis and accumulation by spinal cord cultures}

The cultures were pre-incubated for $30 \mathrm{~min}$ with the medium used for non-neuronal cell cultures but lacking choline chloride, and they were incubated for $5 \mathrm{hr}$ at $37^{\circ} \mathrm{C}$ in $120 \mu \mathrm{l}$ (24-well plates) or $50 \mu \mathrm{l}$ (96-well plates) of the same medium supplemented with $12 \mu \mathrm{M}\left[{ }^{3} \mathrm{H}\right]$ choline. To increase the sensitivity of the assay, the isotope $(80 \mathrm{Ci} / \mathrm{mmol})$ was used without isotopic dilution. Thus, the final $\left[{ }^{3} \mathrm{H}\right]$ choline concentration was smaller than the concentration used for sympathetic neuron cultures (see below). The cultures were rinsed with plating medium and dissolved in $100 \mu \mathrm{l}$ or $30 \mu \mathrm{l}$ of formic acid-acetic acid buffer ( $\mathrm{pH} 1.9$ ) containing $1 \%$ SDS. The $\left[{ }^{3} \mathrm{H}\right] \mathrm{ACh}$ synthesized and stored by the cultures was then separated by high voltage paper electrophoresis (Hildebrand et al., 1971) and countcd as described (Hawrot and Patterson, 1979). Sympathetic neuron cultures were incubated with $80 \mu \mathrm{M}\left[{ }^{3} \mathrm{H}\right]$ choline $(0.5 \mathrm{Ci} / \mathrm{mmol})$ and 80 $\mu \mathrm{M}$ [ring $3,5-{ }^{3} \mathrm{H}$ ]tyrosine $(1 \mathrm{Ci} / \mathrm{mmol})$ as described (Swerts et al., 1983). The data were analyzed by a multiple-way variance analysis, and the significance of the data was assessed with the Student's $t$ test.

\section{Partial purification of the active factor from muscle CM}

The active factor from rat skeletal muscle $\mathrm{CM}$ was partially purified by one of the two following methods:

Scheme 1. CM (1.6 l) was supplemented with $0.3 \mathrm{mM}$ phenylmethylsulfonyl fluoride (PMSF), $2.5 \mathrm{mM} \mathrm{Na}$ EGTA and with solid ammonium sulfate to $60 \%$ saturation at $4^{\circ} \mathrm{C}$. After centrifugation, the supernatant was precipitated at saturation in salt, and the resulting pellet was dialyzed for 2 days against $5 \mathrm{mM}$ sodium phosphate buffer, pH 7.0, 0.2 mM Na EGTA (buffer A). This material was applied on a column containing $30 \mathrm{gm}$ of DEAE-cellulose in buffer A, and the flow-through was immediately applied on a column containing $10 \mathrm{gm}$ of CM-cellulose in buffer A. The material $(17 \mathrm{ml})$ eluted from the latter column with $0.2 \mathrm{M} \mathrm{NaCl}, 5 \mathrm{mM}$ sodium phosphate buffer, pH 7.0 (buffer B) was applied on a hydroxyapatite column (Ultrogel HA, LKB) in buffer B. The active fractions in the flow-through (first $55 \mathrm{ml}$ ) were dialyzed against $0.1 \mathrm{M} \mathrm{NH}_{4}$ acetate and lyophilized (Weber and Le Van Thai, 1982). From 1.6 liters of CM, $8.3 \mathrm{mg}$ of protein were obtained at that stage.

Scheme 2. CM was fractionated by adsorption on hydroxyapatite, precipitation with ammonium sulfate, and chromatographed on DEAE- and CM-cellulose columns as described (Swerts et al., 1983).

\section{Enzymatic assays}

Cultures were rinsed with serum-free medium and dissolved in $50 \mu \mathrm{l}$ of $1 \mathrm{M} \mathrm{NaCl}, 5 \mathrm{~mm}$ sodium phosphate buffer, $\mathrm{pH} 6.8,0.2 \%$ Triton $\mathrm{X}-100$. The cells were disrupted by a brief sonication (about $1 \mathrm{sec}$ ) with a Branson sonifier and were centrifuged at $12,000 \times \mathrm{g}$ for $2 \mathrm{~min}$. CAT (E.C. 2.3.1.6) was assayed in the supernatant by the method of Fonnum (1975) and AChE (E.C. 3.1.1.7) by the method of Ellman et al. (1961) using acetylthiocholine as substrate. Lactate dehydrogenase (LDH, E.C. 1.1.1.27) was assayed by the method of Kornberg (1955). 
Minor modifications of the published methods are described elsewhere (Swerts et al., 1983). Protein was assayed by the Folin method (Lowry et al., 1951) using bovine serum albumin as standard.

\section{Immunodetection of the 200-k subunit of neurofilaments}

Spinal cord cells were grown on polyornithine-coated coverslips (Sigma, $M_{\mathrm{r}}$, $=100,000$ to 200,$000 ; 0.1 \mathrm{mg} / \mathrm{ml}$ in $0.15 \mathrm{M}$ borate buffer, $\mathrm{pH}$ 8.4). The cultures were fixed for $30 \mathrm{~min}$ in $3 \%$ formalin at $37^{\circ} \mathrm{C}$, followed by $6 \mathrm{~min}$ in methanol at $-20^{\circ} \mathrm{C}$. The cells were then treated for 2 min with $150 \mathrm{~mm} \mathrm{NaCl}, 10 \mathrm{~mm}$ sodium phosphate, $\mathrm{pH}$ 7.4 (PBS) containing $0.2 \%$ Triton X 100, and they were rinsed with PBS and PBS containing $0.1 \%$ Tween 20 . The cultures were then stained with affinity-purified rabbit antibodies raised against the $200-\mathrm{k}$ subunit of neurofilaments (Paulin et al., 1982; Prochiantz et al., 1982) diluted in PBS-Tween containing 3\% BSA, followed by fluorescein-labeled goat anti-rabbit IgG antibodies (Nordic, The Netherlands). The coverslips were washed with PBS-Tween and mounted in Mowiol 4-88 (Hoechst) (Osborn and Weber, 1982). When immunoperoxidase staining was used, the coverslips were incubated with peroxidase-labeled goat anti-rabbit IgG antibodies (Nordic). Peroxidase activity was revealed by incubation for $5 \mathrm{~min}$ in $0.1 \mathrm{M}$ Tris-IICl buffer, $\mathrm{pH} 7.6$, containing $0.5 \mathrm{mg} / \mathrm{ml}$ of $3-3^{\prime}$-diaminobenzidine (Prolabo, Paris) and $0.03 \% \mathrm{H}_{2} \mathrm{O}_{2}$.

\section{Results}

Aspects of the cultures. Cells dissociated from rat embryonic spinal cord survived without clumping for 3 to 4 weeks in poly-L-lysine-coated dishes, whereas cells plated either on poly-L-ornithine or on the substratum attached material deposited on tissue culture dishes by skin fibroblasts or cardiac myocytes (Hawrot, 1980) had a strong tendency to reaggregate and to detach from the culture dish. As these cultures were not treated with antimitotic drugs, non-neuronal cells proliferated rapidly during the first 5 to 6 days until they reached confluency. After 4 days, highly branched, phase-bright cells with bipolar and multipolar morphologies were clearly seen on top of the background of non-neuronal cells. In cultures plated at very low density, virtually all cells with long cytoplasmic extensions were labeled with affinity-purified antibodies against the $200-\mathrm{k}$ subunit of the neurofilament protein, demonstrating their neuronal nature (Fig. 1).

Effect of muscle CM on $\left.{ }^{3} \mathrm{H}\right] \mathrm{ACh}$ synthesis and storage by spinal cord cultures. Spinal cord cells were plated at varying densities corresponding to 1 to $4 \times 10^{5}$ cells/16$\mathrm{mm}$ dish and were grown for 15 days in the absence or presence of $50 \%$ muscle $\mathrm{CM}$. Under both culture conditions, $\left[{ }^{3} \mathrm{H}\right] \mathrm{ACh}$ synthesis and accumulation increased with cell density up to $2 \times 10^{5}$ cells plated per dish and then stayed constant up to at least $4 \times 10^{5}$ cells/dish (Fig. 2). A 3- to 4-fold increase in $\left[{ }^{3} \mathrm{H}\right] \mathrm{ACh}$ synthesis and accumulation was observed for each cell density tested in cultures grown with serum containing CM. On the other hand, the CM obtained by incubating dense muscle cultures in serum-free L-15- $\mathrm{CO}_{2}$ was inactive (data not shown).

Comparison of enzyme activities in cultures grown with and without $C M$. The variations in $\left[{ }^{3} \mathrm{H}\right] \mathrm{ACh}$ synthesis and storage and in CAT and AChE activities have been compared in sister SC cultures grown for 1 to 3 weeks in the absence or presence of $50 \%$ CM (Fig. 3).

In cultures grown for 7 days in $\mathrm{CM}$, both $\left[{ }^{3} \mathrm{H}\right] \mathrm{ACh}$ synthesis and storage and CA'I' activity were significantly increased over cultures grown without CM. Nearly maximal CAT activity in cultures grown with $\mathrm{CM}$ was obtained after 7 days, whereas a 2.3 -fold increase in $\left[{ }^{3} \mathrm{H}\right]$ ACh synthesis and storage was observed between days 7 and 14 , with no significant variation in the following week. On the other hand, AChE activity was identical in 7-day-old cultures grown with and without $\mathrm{CM}$, but was increased 3.5 to 4.2 -fold in cultures grown with $\mathrm{CM}$ for both 14 and 21 days. In the experiment of Figure 3, the ratios of the protein contents of the cultures grown with and without CM were $1.04,1.25$, and 1.36 for 7-, 14-, and 21-day-old cultures, respectively. In four independent experiments involving 2415-day-old cultures, the protein contents of cultures grown with and without CM were $287 \pm 31 \mu \mathrm{g} /$ dish (mean $\pm \mathrm{SEM}$ ) and $249 \pm 21 \mu \mathrm{g} / \mathrm{dish}$, respectively. Thus, CM caused a slight increase in the total protein, but the difference did not reach the level of significance. As found with sympathetic neuron cultures (Swerts et al., 1983), the specific activity of lactate dehydrogenase was identical in SC cultures grown for 15 days with and without $\mathrm{CM}$ (respectively, $796 \pm 43$ and $800 \pm 65 \mathrm{pmol} / \mathrm{min} \times$ micrograms of protein, $n=3$ ), suggesting that $\mathrm{CM}$ did not affect the overall growth of the cultures.

Comparison of the effects of CMs from various sources on spinal cord and sympathetic ganglion cultures. Identical batches of CM from different types of cell cultures were tested for their effect on $\left[{ }^{3} \mathrm{H}\right] \mathrm{ACh}$ synthesis and accumulation by spinal cord cell cultures and by sympathetic neuron cultures. For both types of neuron cultures, the most active CMs were obtained with primarv or secondary cultures of newborn rat skeletal muscle cells or skin fibroblasts (Table I, A to C). Thus, these CMs were always used as a reference to assess the effects of CMs from other sources. Rat heart CM was almost as active as rat skeletal muscle $\mathrm{CM}$ on spinal cord cultures (data not shown), whereas CM from $\mathrm{C} 6$ glioma cells was slightly less active (Table I, B). On the other hand, rat brain CM was inactive on spinal cord cultures and only weakly active on sympathetic neuron cultures (Table I, A). A similar order of potency (skeletal muscle $>$ heart $>\mathrm{C}_{6}$ glioma $>$ brain) was found by Patterson and Chun (1977) with sympathetic neuron cultures. We also found that CMs from mouse heart cells and mouse 3T3 were inactive on spinal cord cultures and 6- to 8-fold less active than rat heart or muscle $\mathrm{CM}$ on sympathetic neurons. Several rat cell lines were also screened. PYT21 was obtained by inserting into FR 3 T3 fibroblasts the part of polyoma virus genome coding for $T$ antigens (Rassoulzadegan et al., 1982). L6 (clone 5) was a fusing subclone of L6 myoblasts, and L6NF was a nonfusing, rapidly dividing subclone of the same origin (C. Pinset and $\mathrm{R}$. Whalen, unpublished data). The CMs from these three cell lines were weakly active or inactive when tested on both spinal cord cultures and sympathetic neuron cultures (Table I, C). 

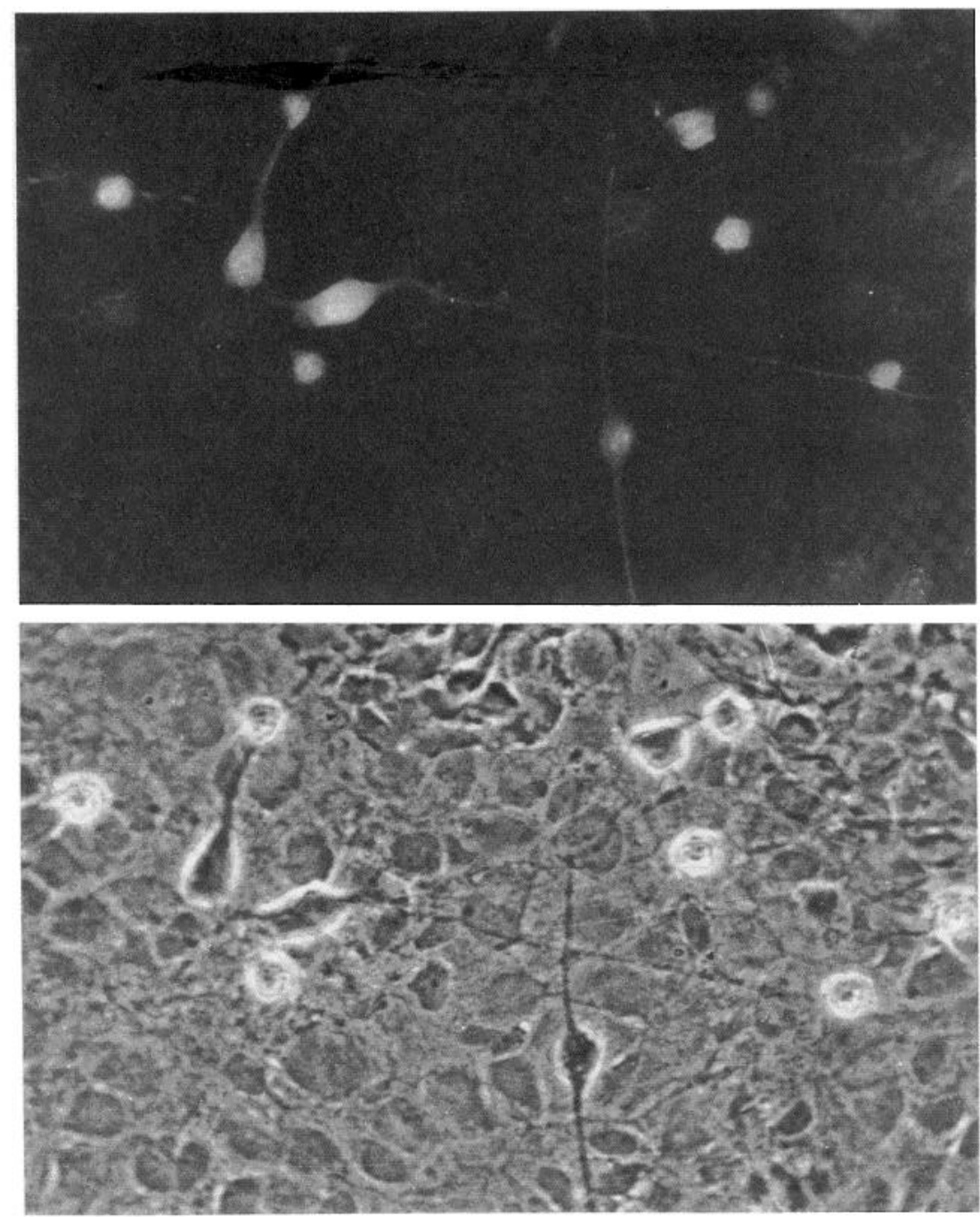

Figure 1. Staining of the $200-\mathrm{k}$ neurofilament protein in spinal cord cultures. Immunofluorescence staining and phase contrast of the same field of a 21-day-old culture. Magnification $\times 448$. This experiment was performed by M. E. Sauron in collaboration with Dr. D. Paulin (Paris).

From these limited data, a correlation of the activities of the CMs tested on both types of neuron cultures obviously could not be statistically demonstrated. However, it appeared that the most active CMs on spinal cord cultures were also the most active on sympathetic neurons, although the stimulation of $\left[{ }^{3} \mathrm{H}\right] \mathrm{ACh}$ synthesis and accumulation was one order of magnitude larger with the latter neuron cultures. On the other hand, the $\mathrm{CMs}$ that were inactive or weakly active on spinal cord cultures were also weakly active on sympathetic neurons, although no $\mathrm{CM}$ was strictly inactive on the latter cultures. Thus, this comparison suggested that the CM factors active on spinal cord cells (SC-CMF) and on sympathetic neurons (SCG-CMF) were somehow related, and this prompted us to study whether they would copurify.

Fractionation of CM protein and comparison of the effects on spinal cord and sympathetic neuron cultures. In the past few years, a four-step fractionation scheme has been devised which allows a partial purification of SCG-
CMF (Weber, 1981; Swerts et al., 1983). This scheme was applied to skeletal muscle CM, and the fractions were tested for their effects on ACh synthesis by spinal cord cultures. In a first series of experiments, CM was mixed with phosphate calcium gel under conditions where $97 \%$ of CM protein bound to the gel (Swerts et al., 1983). The unbound material was further fractionated by ammonium sulfate precipitation. The protein that precipitated between 0 and $60 \%$ saturation in salt was inactive (data not shown); the material that precipitated between 60 and $100 \%$ saturation (P 100 fraction) increased $\left[{ }^{3} \mathrm{H}\right] \mathrm{ACh}$ synthesis and storage by $\mathrm{SC}$ cultures in a dose-dependent manner (Table II, A). The P 100 fraction was then further purified by chromatography on DEAE- and CM-cellulose columns. As found for SCGCMF (Weber, 1981), the material active on spinal cord cultures was quantitatively recovered in the fraction unbound by a DEAE-cellulose column in $5 \mathrm{~mm}$ sodium phosphate buffer, pH 7 (Table II, B), resulting in a 30 fold purification over the P 100 fraction. The DEAE- 
cellulose fraction was then applied on a CM-cellulose column in the same buffer. The activity was eluted stepwise with $0.25 \mathrm{M} \mathrm{NaCl}, 5 \mathrm{mM}$ sodium phosphate buffer, resulting in a further 1.4-fold purification (Table II, B).

No attempt has been made to compare the behavior of SCG-CMF and SC-CMF during an elution of the CMcellulose column with a linear salt gradient. In addition, the fractions used in experiment B of Table II were only assayed at one protein concentration without determination of a complete dose-response curve for each of them. Thus, these data do not allow the calculation of purification factors and yields for the four fractionation steps. However, identical stimulations of $\left[{ }^{3} \mathrm{H}\right] \mathrm{ACh}$ syn-



Figure 2. Influence of cell density on $\left[{ }^{3} \mathrm{H}\right] \mathrm{ACh}$ synthesis and accumulation by spinal cord cell cultures. Dissociated spinal cord cells were plated in $2-\mathrm{cm}^{2}$ poly-L-lysine-coated dishes at the indicated density and grown for 14 days with $(\mathbf{A})$ or without (O) $50 \%$ muscle CM. The synthesis and storage of $\left[{ }^{3} \mathrm{H}\right] \mathrm{ACh}$ was measured on quintuplicate sister cultures. Error bars represent SEM. thesis were observed with the different fractions tested at the same equivalent percentage of $\mathrm{CM}$ (see legend of Table II), suggesting that the recovery of activity from the DEAE- and CM-cellulose columns was nearly quantitative. Thus, these experiments indicated that SC-CMF

TABLE I

Effects of CM from various cell cultures on $\left[{ }^{3} H\right] A C h$ synthesis and accumulation by spinal cord cell cultures and sympathetic neuron cultures

CM was collected after 24-hr contact with confluent cultures of nonneuronal cells and diluted 2-fold with fresh culture medium for spinal cord cells or sympathetic neurons. Neuron cultures were tested for $\left[{ }^{3} \mathrm{H}\right]$ ACh synthesis and accumulation after 10 to 14 days in $50 \% \mathrm{CM}$. In experiments $A$ to $C$, the data are from sister neuron cultures.

\begin{tabular}{llc}
\hline \multirow{2}{*}{ Source of CM } & \multicolumn{2}{c}{$\left.{ }^{3} \mathrm{H}\right]$ ACh Synthesis and Storage } \\
\cline { 2 - 3 } & $\begin{array}{c}\text { Spinal Cord } \\
\text { Cell Cultures }\end{array}$ & $\begin{array}{c}\text { Sympathetic } \\
\text { Neuron Cultures }\end{array}$ \\
\hline & \multicolumn{2}{c}{ pmol/dish } \\
Experiment A & $0.26 \pm 0.02$ & $0.5 \pm 0.2$ \\
$\quad$ No CM & $0.84 \pm 0.02^{a}$ & $71 \pm 1$ \\
Rat skeletal muscle & $0.74 \pm 0.02^{a}$ & $94 \pm 7$ \\
Rat skin fibroblasts & $0.34 \pm 0.01^{b}$ & $16 \pm 1$ \\
Rat brain & $0.36 \pm 0.06^{b}$ & $3.9 \pm 0.6$ \\
Mouse heart & $0.36 \pm 0.06^{b}$ & $9 \pm 3$ \\
Mouse 3T3 & \multicolumn{2}{c}{} \\
Experiment B & $0.28 \pm 0.01$ & $\mathrm{ND}$ \\
No CM & $1.12 \pm 0.02^{a}$ & $\mathrm{ND}$ \\
Rat skeletal muscle & $0.83 \pm 0.03^{a}$ & $\mathrm{ND}$ \\
C glioma cells & & \\
Experiment C & $0.25 \pm 0.01$ & $3.7 \pm 0.7$ \\
No CM & $0.79 \pm 0.05^{a}$ & $\mathrm{ND}$ \\
Rat skeletal muscle & $\mathrm{ND}$ & $200 \pm 30$ \\
Rat heart & $0.46 \pm 0.02^{a}$ & $33 \pm 5$ \\
PYT21 fibroblasts & $0.46 \pm 0.05^{a}$ & $37 \pm 1$ \\
L6 (clone 5) myoblasts & $0.26 \pm 0.02^{b}$ & $16 \pm 4$ \\
L6 NF myoblasts & & \\
\hline
\end{tabular}

${ }^{a} p<0.001$ versus "no CM" condition.

${ }^{b}$ No significant difference from "no CM" condition.

${ }^{c} \mathrm{ND}$, not determined.
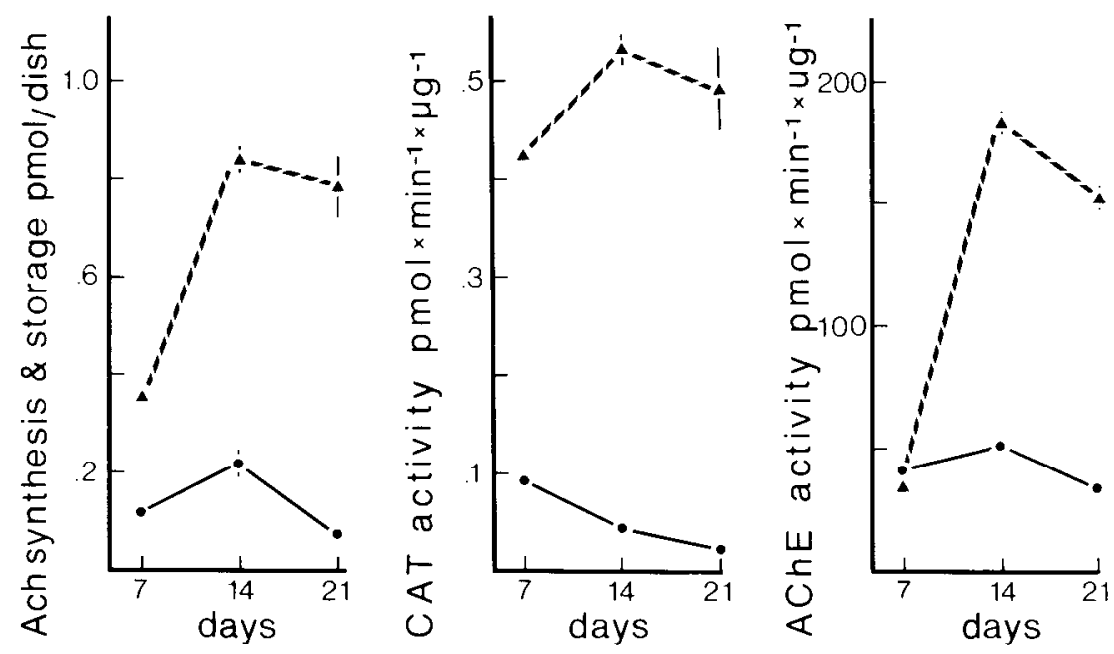

Figure 3. Time course of acetylcholine metabolism in cultures grown with and without CM. Thirty-six sister spinal cord cultures were grown from day 0 either without $(\bullet)$ or with $(\boldsymbol{\Lambda}) 50 \%$ muscle $\mathrm{CM}$. At each time period, three cultures of each group were tested for $\left[{ }^{3} \mathrm{H}\right] \mathrm{ACh}$ synthesis storage, and three others were used for CAT and AChE determinations. SEM are given by the error bars and, when not indicated, are less than the width of the symbols. 
TABLE II

Partial purification of the CM factor by following its effects on $\left[{ }^{3} \mathrm{H}\right] \mathrm{ACh}$ synthesis and storage by spinal cord cell cultures

In experiment $\mathrm{A}$, muscle $\mathrm{CM}$ was fractionated by absorption on a phosphate calcium gel and precipitation with ammonium sulfate as described under "Materials and Methods." The P 100 fraction was dialyzed against Hanks' saline solution and mixed to the culture medium for spinal cord cells at the indicated protein concentration. An equivalent percentage of $\mathrm{CM}$ of $n \times 100 \%$ means that the material mixed to $1 \mathrm{ml}$ of culture medium was obtained from $n$ milliliters CM. In experiment B, muscle CM was fractionated following scheme 2 described under "Materials and Methods." For experiments A and B, spinal cord cultures were maintained in the different media between days 0 and 14 . Data are mean \pm SEM for $n=5$.

\begin{tabular}{|c|c|c|c|c|}
\hline & \multicolumn{2}{|c|}{ Protein Added to Culture Medium } & \multicolumn{2}{|c|}{$\left[{ }^{3} \mathrm{H}\right] \mathrm{ACh}$ Synthesis and Storage } \\
\hline & $\begin{array}{l}\text { Micrograms per } \\
\text { milliliter }\end{array}$ & $\begin{array}{l}\text { Equivalent } \\
\text { percentage } \\
\text { of } \mathrm{CM}\end{array}$ & $\begin{array}{l}\text { Picomoles per } \\
\text { Dish }\end{array}$ & $\begin{array}{l}\text { Percentage of } \\
\text { Control Value }\end{array}$ \\
\hline \multicolumn{5}{|l|}{ Experiment A } \\
\hline Control & 0 & 0 & $0.48 \pm 0.05$ & 100 \\
\hline P 100 fraction & 85 & 100 & $0.78 \pm 0.05^{a}$ & 162 \\
\hline P 100 fraction & 170 & 200 & $0.82 \pm 0.04^{a}$ & 171 \\
\hline P 100 fraction & 340 & 400 & $0.89 \pm 0.08^{b}$ & 185 \\
\hline P 100 fraction & 680 & 800 & $1.00 \pm 0.02^{b}$ & 208 \\
\hline \multicolumn{5}{|l|}{ Experiment B } \\
\hline Control & 0 & 0 & $0.25 \pm 0.02$ & 100 \\
\hline $50 \% \mathrm{CM}$ & $\mathrm{ND}^{r}$ & 50 & $0.68 \pm 0.03^{h}$ & 270 \\
\hline P 100 fraction & 170 & 200 & $0.46 \pm 0.02^{b}$ & 180 \\
\hline DEAE-cellulose fraction & 5.7 & 200 & $0.46 \pm 0.02^{b}$ & 180 \\
\hline CM-cellulose fraction & 4.2 & 200 & $0.50 \pm 0.02^{b}$ & 200 \\
\hline
\end{tabular}

behaved as SCG-CMF during the four purification steps used (Swerts et al., 1983).

In a second series of experiments, dose-response curves were established for the CM-cellulose fraction tested in parallel on spinal cord cell cultures and sympathetic neuron cultures (Fig. 4). With spinal cord cells, a maximal 4 -fold increase in $\left[{ }^{3} \mathrm{H}\right] \mathrm{ACh}$ synthesis and storage was measured with $30 \mu \mathrm{g}$ of protein $/ \mathrm{ml}$; half-maximal effect was obtained with $10 \mu \mathrm{g} / \mathrm{ml}$. On the other hand, a 30 - to 50 -fold increase in $\left[{ }^{3} \mathrm{H}\right] \mathrm{ACh}$ synthesis and storage by sympathetic neuron cultures was obtained with 30 to $100 \mu \mathrm{g} / \mathrm{ml}$. With these cultures, a concomitant decrease in $\left[{ }^{3} \mathrm{H}\right]$ catecholamine synthesis and storage was observed, as first described by Patterson and Chun (1977) with heart CM. A maximal 2-fold decrease was obtained with 30 to $100 \mu \mathrm{g} / \mathrm{ml}$; half-maximal effect took place around $10 \mu \mathrm{g} / \mathrm{ml}$.

Effects of purified CM factor on CAT and AChE aclivities in spinal cord cell cultures. The material purified from muscle CM (in four steps) was mixed with culture medium $(12 \mu \mathrm{g}$ of protein $/ \mathrm{ml})$ and given to spinal cord cell cultures for a variable period. A 3.3-fold increase in CAT activity over control sister cultures was observed after 7 days. This figure increased to 3.5 and 4.8 after 14 and 21 days, respectively (Fig. 5). A 1.6 to 2.2 -fold increase in $\mathrm{AChE}$ specific activity was concomitantly observed at each time point studied. This effect appeared smaller than the 3.5 to 4.2 -fold increase observed by comparing cultures grown with and without CM (Fig. 3), but the difference between the two experiments resulted largely from an unexplained variability of AChE development in control cultures. The ratios of the protein contents of the cultures grown with and without the purified factor were $0.80,1.17$, and 1.01 for 7-, 14-, and 21-day-old cultures, respectively, suggesting that the factor had no effect on the overall growth on the SC cultures.

\section{Discussion}

Regulation of ACh synthesis in dissociated SC cell cultures. In agreement with earlier studies performed on mouse SC cell cultures (Giller et al., 1977; Meyer et al., 1979; Godfrey et al., 1980), a 3- to 5-fold increase in both CAT specific activity and $\left[{ }^{3} \mathrm{H}\right] \mathrm{ACh}$ synthesis and storage was measured in rat SC cultures grown for 1 to 3 weeks in the presence of muscle $\mathrm{CM}$. On the other hand, the activity of lactate dehydrogenase was not modified by growing the SC cells in CM. The similarities of the activities of creative phosphokinase, phosphoglucomutase, and myokinase in cultures grown with and without CM have also been demonstrated by Giller et al. (1977). Thus, these results suggest that CM is specifically involved in the regulation of a limited set of enzyme activities in these cultures. We also demonstrated that the increase in $\left[{ }^{3} \mathrm{H}\right] \mathrm{ACl}$ synthesis and accumulation by $\mathrm{CM}$ occurred in a wide range of cell densities, and that the effect of $\mathrm{CM}$ could not be mimicked by increasing the cell density above $2 \times 10^{5}$ cells/dish. This is an important control, as CAT specific activity (i.e., per milligram of protein) increases with cell density in other cell cultures (Schubert et al., 1977; Lucas et al., 1979). $\left[{ }^{3} \mathrm{H}\right] \mathrm{ACh}$ synthesis and storage by $\mathrm{SC}$ cultures grown with and without $\mathrm{CM}$ reached a plateau for initial cell densities larger than $2 \times 10^{5}$ cells $/$ dish $\left(1 \times 10^{5}\right.$ cells $/$ $\mathrm{cm}^{2}$ ). The origin of this saturation is not known. A similar effect has been observed at similar cell densities with chick embryo SC cultures (Berg, 1978) but not with human SC cultures (A. C. Kato and G. Touzeau, unpublished data).

Regulation by CM of AChE activity in SC cultures. We found that AChE activity was significantly higher in SC cultures grown with $\mathrm{CM}$ than without $\mathrm{CM}$. However, this difference was only seen after 2 weeks in culture, 


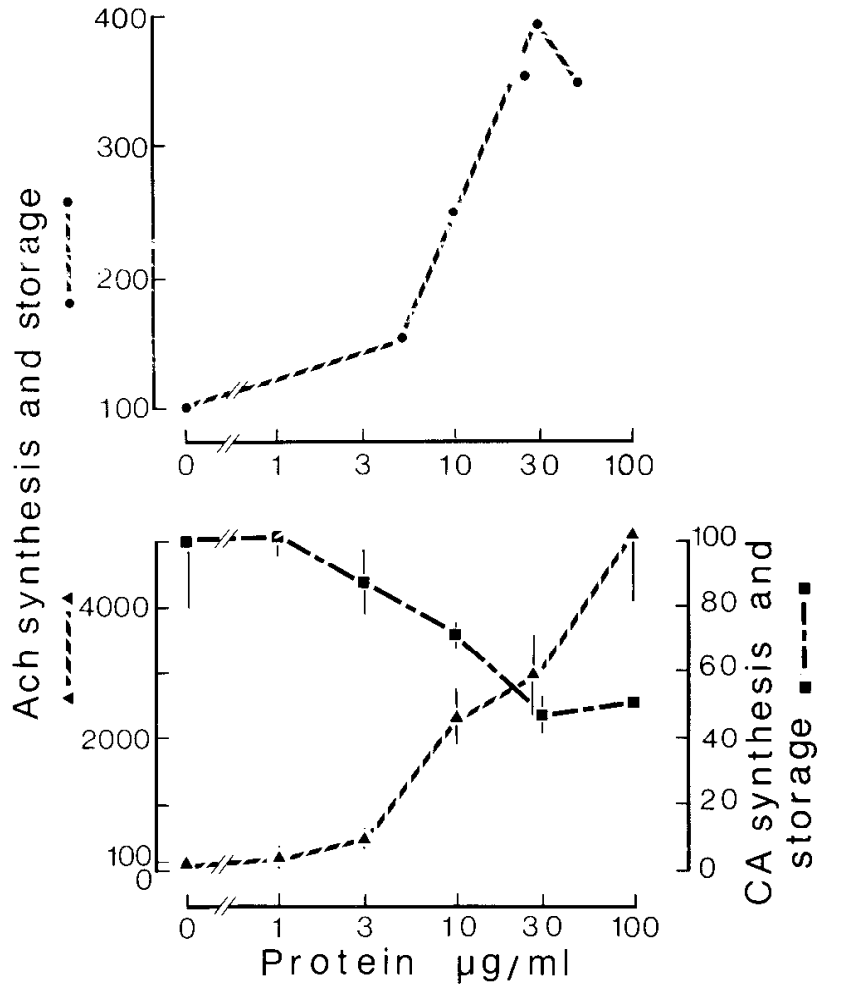

Figure 4. Dose-response curves of the partially purified CM factor determined with spinal cord cell cultures and sympathetic neuron cultures. CM factor was purified according to scheme 2 described under "Materials and Methods" and mixed to culture media at the indicated protein concentration. Upper panel, Effects on spinal cord cell cultures. CM factor was given to the cultures between days 0 and 15 , before $\left[{ }^{3} \mathrm{H}\right] \mathrm{ACh}$ synthesis and storage was measured (O). Lower panel, Effects on sympathetic neuron cultures. Neuron cultures were maintained in the presence of CM factor between days 2 and 13 and tested simultaneously for the synthesis and storage of $\left[{ }^{3} \mathrm{H}\right] \mathrm{ACh}$ from $\left[{ }^{3} \mathrm{H}\right]$ choline $(\boldsymbol{\Delta})$ and of $\left[{ }^{3} \mathrm{H}\right]$ catecholamine $\left(\left[{ }^{3} \mathrm{H}\right] \mathrm{CA}\right)$ from $\left[{ }^{3} \mathrm{H}\right]$ tyrosine ( $\mathbf{\square})$ as described by Patterson and Chun (1977). The data are all expressed as the percentage of the control values and are given as mean \pm SEM for $n=5$ (upper panel) or $n=$ 3 (lower panel).

whereas the difference in CAT activity was already nearly maximal after 1 week. Thus, our results seem to contradict the results of Giller et al. (1977) and of Brookes et al. (1980), who demonstrated that AChE activity in mouse SC cultures was unaffected by CM. Although species differences cannot be excluded, our data suggest that the regulation of $\mathrm{AChE}$ may have been overlooked if mouse SC cultures were not exposed to CM for a long enough period of time.

The increases in both CAT and AChE activities in SC cultures grown with CM or with the partially purified CM factor contrast with our results on dissociated neuron cultures from newborn rat SCG (Swerts et al., 1983) and nodose ganglia (C. Mathieu, A. Moisand, and M. J. Weber, submitted for publication). In the latter two culture systems, the increase in CAT activity caused by $\mathrm{CM}$ was accompanied by a decrease in AChE activity. In SCG cultures, this 2- to 3-fold decrease in total activity was accompanied by a dramatic decrease in the $16 \mathrm{~S}$ form of the enzyme (Swerts et al., 1984a). As we suggest that the same CM factor is active on SC, SCG, and nodose ganglia (see below and C. Mathieu, A. Moisand, and M.
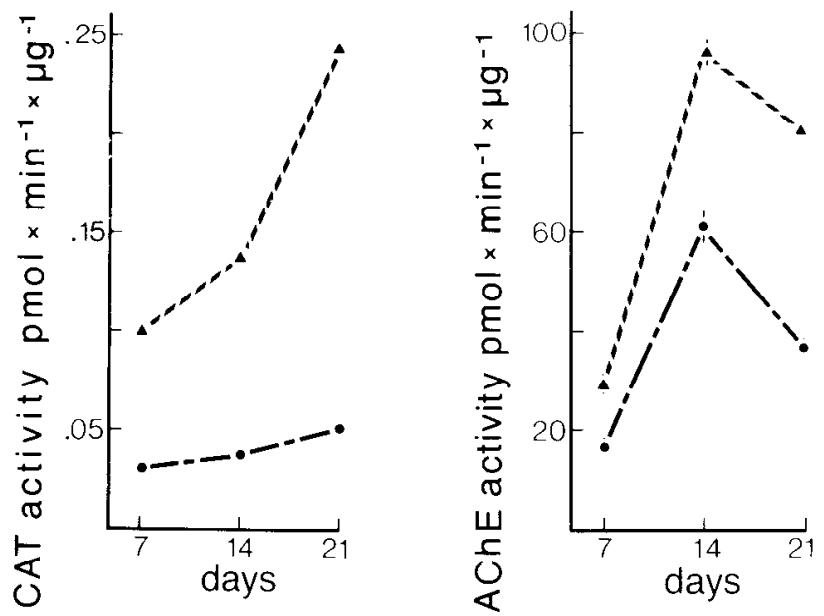

Figure 5. Time course of the effects of partially purified CM factor on CAT and AChE activities in spinal cord cell cultures. The CM factor was purified following scheme 1 described under "Materials and Methods" and mixed to culture medium at 12 $\mu \mathrm{g}$ of protein $/ \mathrm{ml}$. After the indicated culture time, spinal cord cells were harvested and tested for CAT and AChE activities. $\boldsymbol{\Delta}--\boldsymbol{\Lambda}$, cultures grown with CM factor; $\mathbf{O}_{-}-\mathbf{-}$, cultures grown without CM factor. When not indicated, SEM are less than the width of the symbols.

J. Weber, submitted for publication), this extracellular signal may regulate $\mathrm{AChE}$ activity in opposite directions for the SC cultures and for the SCG and nodose ganglion cultures. These differences may possibly reflect the differences in the embryological origin of the different cultures.

Comparison of the CM factors acting on SC and SCG cultures. Several series of data suggest that the same macromolecular factor from CM regulates CAT activity in SC and in SCG neuron cultures.

1. Identical batches of CMs from various types of nonneuronal cells were tested on both types of cultures. The increase in $\left[{ }^{3} \mathrm{H}\right] \mathrm{ACh}$ synthesis and storage observed in SCG cultures grown with the most active CMs was more than one order of magnitude larger than the response of $\mathrm{SC}$ cultures, a situation which made difficult a quantitative correlation between the two systems. Nevertheless, we observed that the most active CMs for both neuron cultures were made by muscle cells $>$ heart cells $>\mathrm{C}_{6}$ glioma cells. The same rank in activity was documented by Patterson and Chun (1977) for SCG cultures. Also in agreement with these authors, CM from mouse heart cells was strikingly less active than its rat counterpart when tested on both SCG and SC cultures, suggesting a certain degree of species specificity. Finally, CMs from a variety of other non-neuronal cell cultures were inactive or weakly active on both types of neuron cultures. Taken together, these data suggest that SCG-CMF and SCCMF present similarities in their cellular sources in vitro.

2. The CM obtained after the incubation of confluent muscle cells with serum-free $\mathrm{L}-15-\mathrm{CO}_{2}$ is inactive on SC cultures (data not shown) and on SCG cultures (Weber et al., 1979; Fukada, 1980). This obviously may be fortuitous, and further work is necessary to assess if the release of $\mathrm{SC}-\mathrm{CMF}$ in serum-free medium is under the same hormonal control as SCG-CMF (Fukada, 1980). For unknown reasons, our results contrast with those of 
Godfrey et al. (1980), who reported that serum-free muscle $\mathrm{CM}$ was as active as serum-containing $\mathrm{CM}$ on mouse $\mathrm{SC}$ cultures.

3. SC-CMF and SCG-CMF co-purified during a purification scheme involving an adsorption on hydroxyapatite, a fractionation by ammononium sulfate precipitation, and sequential chromatography on DEAE- and CMcellulose columns. For both biological activities, a several thousand-fold purification was achieved. Since a purification to homogeneity has not yet been obtained, it is still possible that SC-CMF and SCG-CMF are distinct molecules having similar molecular properties. However, it is intriguing that both activities did not bind to hydroxyapatite at low phosphate concentration and moderate ionic strength, conditions under which $97 \%$ of $\mathrm{CM}$ protein bound to the gel. Another possibility may be that SC-CMF and SCG-CMF are distinct macromolecules linked by noncovalent bonds.

4. The SC-CMF in the most purified fraction we used (CM-cellulose step) increased $\left[{ }^{3} \mathrm{H}\right] \mathrm{ACh}$ synthesis and storage by $\mathrm{SC}$ in a range of concentration of 5 to $50 \mu \mathrm{g}$ of protein/ml of culture medium. This is precisely the range where the same material both increased $\left[{ }^{3} \mathrm{H}\right] \mathrm{ACh}$ synthesis and storage and decreased $\left[{ }^{3} \mathrm{H}\right]$ catecholamine synthesis and storage by SCG neuron cultures. One could obviously argue that the fraction used for this experiment contained by chance the same amount of biological units for two unrelated factors. But the simplest interpretation is that the effects observed on both types of cultures are carried by the same macromolecule.

Thus, none of the arguments listed above is a proof that SC-CMF and SCG-CMF are identical. But the conjunction of all of them makes it an attractive working hypothesis, although a definite demonstration will probably necessitate the obtention of a monoclonal antibody against this factor. Even if it ultimately turns out that SC-CMF and SCG-CMF are, in fact, distinct molecules, our study, nevertheless, provides a scheme for a partial purification of SC-CMF which by itself is a significant progress.

Several laboratories are presently purifying cholinergic factors from various sources, and our experiments raise the possibility of a general cholinergic factor. The SCGCMF has an apparent $M_{\mathrm{r}}=40,000$ to 45,000 when analyzed on Sephadex columns (Weber, 1981), a value close to that found for a factor from ocular tissues which stimulates CAT activity in chick ciliary ganglion cultures (Nishi and Berg, 1981b). A rat muscle factor of $M_{\mathrm{r}}=$ 120,000 as well as a minor component of $M_{\mathrm{r}}=40,000$ promote the survival of chick motoneurons in cultures (reviewed by Slack et al., 1983). Further purification is obviously needed to determine if these three factors present other similarities. On the other hand, SCG-CMF appears different from a muscle factor of $M_{r}=1500$ which stimulates cholinergic development in rat $\mathrm{SC}$ cultures (McManaman et al., 1983; Smith and Appel, 1983) and from an acidic ciliary neuronotrophic factor from ocular tissues (Manthorpe et al., 1980).

T'he mode of action of CM factor on SC neurons. We did not measure the number of cells labeled with antineurofilament antibodies in SC cultures grown with and without CM. However, we found that CMF had no effect on both the total protein content and lactate dehydro- genase activity in the cultures. Although these parameters probably reflect the growth of both neuronal and non-neuronal cells, these data, and also the visual observation of the cultures, suggested that $\mathrm{CM}$ had no dramatic effect on neuronal survival in SC cultures.

Thus, three types of hypotheses can be proposed to explain the increase in CAT activity in cultures grown with CM: (1) SC-CMF increases specifically the survival in culture of cholinergic neurons; (2) SC-CMF increases CAT activity in neurons which already displayed a cholinergic phenotype when placed in culture; (3) SC-CMF induces CAT in neurons which displayed a noncholinergic neurotransmitter phenotype when placed in culture. Our experiments do not allow to distinguish between these possibilities. Bennett et al. (1980) have clearly shown that muscle CM increases the survival of motoneurons in SC cultures from chick embryo, but it is not known if a similar effect occurs in rodent SC cultures. Giller et al. (1973) found that the size of the population of neurons with large cell bodies and long neurites in mouse SC cultures was increased in co-cultures with myotubes. As motoneurons are presumably a part of this neuron population, these data may be compatible with hypothesis 1 . This hypothesis, as well as hypothesis 2 , may be more conveniently tested with appropriate immunological markers for cholinergic cells.

On the other hand, the studies performed on SCG neuron cultures (Reichardt and Patterson, 1977; Potter et al., 1980, 1981) suggest that the CM factor may provoke a modification of the neurotransmitter phenotype in SC ncurons. This hypothesis raises the question of the initial neurotransmitter phenotype of the cells which adopt a cholinergic phenotype when grown in $\mathrm{CM}$. The synthesis and storage of $\left[{ }^{3} \mathrm{H}\right]$ catecholamine from $\left[{ }^{3} \mathrm{H}\right]$ tyrosine and tyrosine hydroxylase activity could not be detected in our SC cultures (M. -C. Giess, unpublished data), suggesting that the starting phenotype of SC neurons is not adrenergic, as it is the case for rat SCG neurons. In agreement with this hypothesis, Giller et al. (1977) reported that the co-culture with myotubes dramatically decreased the activity of glutamate decarboxylase of mouse SC cultures. Although this effect could not be reproduced with muscle CM (Giller et al., 1977), further experiments are needed to test the hypothesis that the cholinergic CM factor may also act as a "repressor" for the synthesis of other neurotransmitters than catecholamines.

\section{References}

Bennett, M. R., and W. White (1979) The survival and development of cholinergic neurons in potassium-enriched media. Brain Res. 173: 549-553.

Bennett, M. R., K. Lai, and V. Nurcombe (1980) Identification of embryonic motoneurons in vitro: Their survival is dependent on skeletal muscle. Brain Res. 190: 537-542.

Berg, D. K. (1978) Acetylcholine synthesis by chick spinal cord neurons in dissociated cell culture. Dev. Biol. 66: 500-512.

Brookes, N., D. R. Burt, A. M. Goldberg, and G. G. Bierkamper (1980) The influence of muscle-conditioned medium on cholinergic maturation in spinal cord cell cultures. Brain Res. 186: 474-479.

Burton, L. E., H. W. Wyndham, and E. M. Shooter (1978) Nerve growth factor in mouse saliva. Rapid isolation proce- 
dures for and characterization of $7 \mathrm{~S}$ nerve growth factor. J. Biol. Chem. 253: 7807-7812.

Chalazonitis, A., and G. D. Fischbach (1980) Elevated potassium induces morphological differentiation of dorsal root ganglionic neurons in dissociated cell culture. Dev. Biol. 78: 173-183.

Dribin, L. B., and J. N. Barrett (1980) Conditioned medium enhances neuritic outgrowth from rat spinal cord explants. Dev. Biol. 74: 184-195.

Ellman, G. L., K. D. Courtney, V. Andres, Jr., and R. M. Featherstone (1961) A new and rapid colorimetric determination of acetylcholinesterase activity. Biochem. Pharmacol. 7: 88-95.

Fonnum, F. (1975) A rapid radiochemical method for the determination of choline acetyltransferase. J. Neurochem. 24: 407-409.

Fukada, K. (1980) Hormonal control of neurotransmitter choice in sympathetic neurone cultures. Nature 287: 553-555.

Giller, E. L., B. K. Schrier, A. Shainberg, H. R. Fisk, and P. G. Nelson (1973) Choline acetyltransferase activity is increased in combined cultures of spinal cord and muscle cells from mice. Science 182: 588-589.

Giller, E. L., J. H. Neale, P. N. Bullock, B. K. Schrier, and P. G. Nelson (1977) Choline acetyltransferase activity of spinal cord cell cultures increased by co-culture with muscle and by muscle-conditioned medium. .J. Cell Biol. 74: 16-29.

Godfrey, E. W., B. K. Schrier, and P. G. Nelson (1980) Source and target cell specificities of a conditioned medium factor that increases choline acetyltransferase activity in cultured spinal cord cells. Dev. Biol. 77: 403-418.

Hamburger, V. (1980) Trophic interactions in neurogenesis: A personal historical account. Annu. Rev. Neurosci. 3: 269278.

Hawrot, E. (1980) Cultured sympathetic neurons: Effects of cell-derived and synthetic substrata on survival and development. Dev. Biol. 74: 136-151.

Hawrot, E., and P. H. Patterson (1979) Long-term culture of dissociated sympathetic neurons. Methods Enzymol. 53: 574584.

Henderson, C. E., M. Huchet, and J. P. Changeux (1981) Neurite outgrowth from embryonic chicken spinal neurons is promoted by media conditioned by muscle cells. Proc. Natl. Acad. Sci. U. S. A. 78: 2625-2629.

Henderson, C. E., M. Huchet, and J. P. Changeux (1983) Denervation increases a neurite promoting activity in extracts of skeletal muscle. Nature 302: 609-611.

Hildebrand, J. G., D. L. Barker, E. Herbert, and E. A. Kravitz (1971) Screening for neurotransmitters: A rapid radiochemical procedure. J. Neurobiol. 2: 231-246.

Kato, A. C., and M. J. Rey (1982) Chick ciliary ganglion in dissociated cell culture. I. Cholinergic properties. Dev. Biol. 94: 121-130.

Kornberg, A. (1955) Lactate dehydrogenase of muscle. Methods Enzymol. 1: 441-443.

Lasher, J., and R. Zagon (1972) The effect of potassium on neuronal differentiation in cultures of dissociated newborn rat cerebellum. Brain Res. 41: 482-486.

Lowry, O. H., N. J. Rosebrough, A. L. Farr, and R. J. Randall (1951) Protein measurement with the Folin phenol reagent. J. Biol. Chem. 193: 265-275.

Lucas, C. A., D. Edgar, and H. Thoenen (1979) Regulation of tyrosine hydroxylase and choline acetyltransferase activities by cell density in the PC12 pheochromocytoma clonal cell line. Exp. Cell Res. 121: 79-86.

Manthorpe, M., S. Skaper, R. Adler, K. Landa, and S. Varon (1980) Cholinergic neuronotrophic factors: Fractionation properties of an extract from selected chick embryonic eye tissues. J. Neurochem. 34: 69-75.

Mc Manaman, J., R. G. Smith, and S. H. Appel (1983) Partial characterization of a peptide that stimulates motoneuron cholinergic development in vitro. J. Cell Biol. 97: 238a.

Meyer, T., W. Burkart, and H. Jockusch (1979) Choline acetyltransferase induction in cultured neurons: Dissociated spinal cord cells are dependent on muscle cells, organotypic explants are not. Ncurosci. Lett. 11: 59-62.

Narayanan, C., and Y. Narayanan (1978) Neuronal adjustments in developing nuclear centers of the chick embryo following transplantation of an additional optic primordium. J. Embryol. Exp. Morphol. 44: 53-70.

Nishi, R., and D. K. Berg (1981a) Effects of high $\mathrm{K}^{+}$concentrations on the growth and development of ciliary ganglion neurons in cell culture. Dev. Biol. 87: 301-307.

Nishi, R., and D. K. Berg (1981b) Two components from eye tissue that differentially stimulate the growth and development of ciliary ganglion neurons in cell culture. J. Neurosci. 1: 505-513.

Oppenheim, R. W., I. W. C. Wang, and J. L. Maderdrut (1978) Cell death of motoneurons in the chick embryo spinal cord. III. The differentiation of motoneurons prior to their induced degeneration following limh-hud removal. J. Comp. Neurol. 177: $87-112$.

Oppenheim, R. W., J. L. Maderdrut, and D. J. Wells (1982) Cell death of motoneurons in the chick embryo spinal cord. VI. Reduction of naturally occurring cell death in the thoracolumbar column of Terni by nerve growth factor. J. Comp. Neurol. 210: 174-189.

Osborn, M., and K. Weber (1982) Immunofluorescence and immunocytochemical procedures with affinity purified antibodies: Tubulin containing structures. Methods Cell Biol. 24: 97-132.

Patterson, P. H. (1978) Environmental determination of autonomic neurotransmitter functions. Annu. Rev. Neurosci. 1: $1-17$.

Patterson, P. H., and L. L. Y. Chun (1977) The induction of acetylcholine synthesis in primary cultures of dissociated rat sympathetic neurons. I. Effects of conditioned medium. Dev. Biol. 56: 263-280.

Paulin, D., H. Jacob, F. Jacob, K. Weber, and M. Osborn (1982) In vitro differentiation of mouse teratocarcinoma cells monitored by intermediate filament expression. Differentiation 22: 90-99.

Pintar, J. E., G. D. Maxwell, K. J. Sweadner, P. H. Patterson, and X. O. Breakefield (1981) Monoamine oxidase activity in early quail embryos and rat neuron cultures with different transmitter phenotypes. Soc. Neurosci. Abstr. 7: 848.

Potter, D. D., S. C. Landis, and E. J. Furshpan (1980). Dual function during development of rat sympathetic neurons in culture. J. Exp. Biol. 89: 57-71.

Potter, D. D., S. C. Landis, and E. J. Furshpan (1981) Adrenergic-cholinergic dual function in cultured sympathetic neurons in rat. Ciba Found. Symp. 83: 123-138.

Prestige, M. C. (1967) The control of cell number in the lumbar ventral horns during the development of Xenopus laevis tadpoles. J. Embryol. Exp. Morphol. 18: 359-387.

Prestige, M. C. (1970) Differentiation, degeneration and the role of the periphery: Quantitative considerations. In The Neurosciences: Second Study Program, pp. 73-82, Rockefeller University Press, New York.

Prochiantz, A., A. Delacourte, M. C. Daguet, and D. Paulin (1982) Intermediate filament proteins in mouse brain cells cultured in the presence or absence of fetal calf serum. Exp. Cell Res. 139: 404-410.

Rassoulzadegan, M., A. Cowie, A. Carr, N. Glaichenhaus, R. Kamen, and F. Cuzin (1982) The roles of individual polyomavirus early proteins in oncogenic transformation. Nature 300: 713-718.

Reichardt, L. F., and P. H. Patterson (1977) Neurotransmitter synthesis and uptake by isolated sympathetic neurons in 
micro cultures. Nature (I.ond.) 270: 147-151.

Schäfer, T., M. E. Schwab, and H. Thoenen (1983) Increased formation of preganglionic synapses and axons due to retrograde trans-synaptic action of nerve growth factor in the rat sympathetic nervous system. J. Neurosci. 3: 1501-1510.

Schubert, D., S. Heinemann, and Y. Kidokoro (1977) Cholinergic metabolism and synapse formation by a rat nerve cell line. Proc. Natl. Acad. Sci. U. S. A. 74: 2579-2583.

Slack, J. R., W. G. Hopkins, and S. Pockett (1983) Evidence for a motor nerve growth factor. Muscle Nerve 6: 243-252.

Smith, R. G., and S. H. Appel (1983) Extracts of skeletal muscle increase neurite outgrowth and cholinergic activity of fetal rat spinal motor neurons. Science 219: 1079-1081.

Swerts, J. P., A. Le Van Thai, A. Vigny, and M. J. Weber (1983) Regulation of enzymes responsible for neurotransmitter synthesis and degradation in cultured rat sympathetic neurons. I. Effects of muscle conditioned medium. Dev. Biol. 100: $1-11$.

Swerts, J. P., A. Le Van Thai, and M. J. Weber (1984a) Regulation of enzymes responsible for neurotransmitter synthesis and degradation in cultured sympathetic neurons. II. Regulation of $16 \mathrm{~S}$ acetylcholinesterase by conditioned medium. Dev. Biol., in press.

Swerts, J. P., M. C. Giess, C. Mathieu, M. E. Sauron, A. Le Van Thai, and M. J. Weber (1984b) Plasticity in the neurotransmitter phenotype of rat sympathetic neurons in primary culture. In The Role of Cell Interaction in Early Neurogenesis,
A. M. Duprat, A. C. Kato, and M. J. Weber, eds., pp. 335-344, NATO Advanced Institutes Series, Plenum Publishing Co., London.

Wang, I. W. C., and R. W. Oppenheim (1978a) Cell death of motoneurons in the chick embryo spinal cord. I. A light and electron microscopic study of naturally occurring and induced cell loss during development. J. Comp. Neurol. 177: 33-58.

Wang, I. W. C., and R. W. Oppenheim (1978b) Cell death of motoneurons in the chick embryo spinal cord. II. A quantitative and qualitative analysis of degeneration in the ventral root, including evidence for axon outgrowth and limb innervation prior to cell death. J. Comp. Neurol. 177: 59-86.

Weber, M. J. (1981) A diffusible factor responsible for the determination of cholinergic functions in cultured sympathetic neurons. Partial purification and characterization. J. Biol. Chem. 256: 3447-3453.

Weber, M. J., and A. Le Van Thai (1982) Progress in the purification of a factor involved in the neurotransmitter choice made by cultured sympathetic neurons. In Embryonic Development. Part B: Cellular Aspects, M. M. Burger and R. Weber, eds., pp. 473-483, A. R. Liss, New York.

Weber, M. J., L. L. Y. Chun, L. F. Reichardt, and P. H. Patterson (1979) Plasticity in the development of sympathetic neurons in primary culture. Gaslini 11: 123-127.

Wolinski, E., and P. H. Patterson (1983) Tyrosine hydroxylase activity decreases with induction of cholinergic properties in cultured sympathetic neurons. J. Neurosci. 3: 1495-1500. 